Board of Governors of the Federal Reserve System

\author{
International Finance Discussion Papers
}

Number 560

August 1996

\title{
THE MANAGEMENT OF FINANCIAL RISKS AT GERMAN NONFINANCIAL FIRMS: THE CASE OF METALLGESELLSCHAFT
}

\author{
Allen B. Frankel and David E. Palmer
}

NOTE: International Finance Discussion Papers are preliminary materials circulated to stimulate discussion and critical comment. References in publications to International Finance Discussion Papers (other than an acknowledgment that the writer has had access to unpublished material) should be cleared with the author or authors. 
In late 1993 and early 1994, the wholly-owned U.S. subsidiary of a German conglomerate experienced substantial losses in connection with the implementation of a petroleum marketing strategy, triggering an emergency recapitalization of the German parent company. The rescue was overseen by the firm's supervisory board, which was chaired by a member of the senior management of the largest German bank. This paper draws on a special auditor's report that examined the nearbankruptcy of the firm, as well as other sources. We develop a case study which finds that the German bank was not well informed as to the formulation and execution of the client firm's risk management strategy that was to be implemented through the large-scale use of financial derivatives. The analysis in the paper raises questions as to whether private information is transmitted efficiently within the bank-based German system of corporate governance. 
The Management of Financial Risks at German Nonfinancial Firms:

The Case of Metallgesellschaft

Allen B. Frankel and David E. Palmer

\section{Introduction}

In Germany, banks are involved with client firms by advancing credit and providing financial services, similar to U.S. commercial banks. German banks also hold equity stakes in firms and exercise proxy rights for firm shares owned by bank clients. The combined exercise of both direct and proxy voting rights can be reflected in the presence of German bank managers on client firms' supervisory boards. It has been theorized in the corporate governance literature that the German model of bank relationships is well designed to minimize agency problems. ${ }^{1}$ In turn, questions have been raised as to what private information is actually distributed within the German system of corporate governance, and how such information is transmitted. ${ }^{2}$

Our paper is a case study of the transmission of private information between Deutsche Bank and one of its large German corporate clients, Metallgesellschaft AG (MG). The paper

\footnotetext{
* The authors are Chief, International Banking Section, and research assistant, respectively, in the Division of International Finance, Board of Governors of the Federal Reserve System. They wish to thank colleagues at the Board of Govemors for comments and suggestions. This paper represents the views of the authors and should not be interpreted as reflecting the views of the Board of Govemors of the Federal Reserve System or other members of its staff. The paper was originally prepared for a June 1996 conference of the American Institute of Contemporary German Studies. We wish to thank attendees of that conference for their comments and suggestions.
} 
draws on a special auditor's report on the near bankruptcy of MG and other materials that provide a rare, if not unique, opportunity to assess information issues associated with the

German system of corporate governance. We focus on MG's formulation and use of financial derivatives to implement a risk management strategy associated with a petroleum marketing initiative.

The MG case attracted substantial public interest in the United States and in Germany. In the United States, the case was widely cited by proponents and opponents of various regulatory proposals for derivatives markets in support of more and less regulation, respectively. In Germany, the case was responsible for a boomlet in interest in the perpetual debate on the role of the German Großbanken in the management of German industrial concerns. In our view, the case raises questions about the efficacy of incentives offered to German banks with respect to their interest in monitoring and assessing the implementation of strategic initiatives by client firms, such as MG's marketing of long-term, fixed price petroleum supply contracts.

\section{Background}

In late 1993 and early 1994, the wholly-owned U.S. subsidiary of a German conglomerate, Metallgesellschaft Corp., experienced losses sufficiently large so as to trigger a DM3.4 billion emergency recapitalization of its German parent company, Metallgesellschaft AG. ${ }^{3}$ The rescue of the MG group was overseen by the parent firm's supervisory board, which was chaired by Deutsche Bank's nominee, Ronaldo Schmitz, a member of Deutsche Bank's management board. ${ }^{4}$ 


\section{$-3-$}

Schmitz had succeeded Dresdner Bank's nominee, Wolfgang Röller, as chair of MG's supervisory board early in 1993 . The alternation of the two banks' nominees as chair of the supervisory board reflected shareholdings and control of proxy voting rights by the two banks that together summed to no less than 40 percent. ${ }^{5}$ The proxy rights assigned to the two banks not only included those of custodial customers but also those associated with the snares held in each bank's investment funds (Kapitalanlagegesellschaften).

In late November 1993, MG's management board disclosed plans to reshape the company and announced that it would pay no dividend for the fiscal year 1992/93 (which had ended on September 30). ${ }^{6}$ Stock analysts concluded that MG had limited prospects for a near-term return to profitability. They attributed their pessimistic assessment of MG, which had grown rapidly through acquisitions in the late 1980s, to the depressed level of metal prices that had left MG very vulnerable to the German recession. The sensitivity of MG's financial position to metal prices had persisted even though the company had become a conglomerate with sizeable trading activities. The analysts' assessments supply contexi to understand why MG had decided to hire Arthur Benson in November 1991 to establish a new business for $\mathrm{MG}^{7}$ The business was to consist of two elements: petroleum product sales and hedges of related contracts.

Benson supposedly put in place a "text-book" hedging strategy to manage market risk associated with an aggressive marketing effort by MG to enter U.S. oil markets. The same basic market opportunity was also independently recognized by the managers of a trading subsidiary of Enron, a publicly-traded U.S. diversified natural gas company. Both MG and Enron offered long-term energy product supply contracts at fixed prices. The business plans 
of the two companies both called for the management of the financial risks of these contracts through exchange-traded and over-the-counter (OTC) derivatives contracts.

The MG episode raised issues about how well German banks can perform as financial monitors of nonfinancial firms, particularly those with sophisticated financing activities. It has been presumed by commentators that the Hausbank relationship, such as existed between Deutsche Bank and MG, involves superior access on the part of the bank to information about the firm's future strategies and financing plans. A highly visible part of the Deutsche BankMG relationship was the chairing of MG's supervisory board by a Deutsche Bank representative. ${ }^{8}$ Materials released in response to public interest in the near-collapse of MG permitted us to assess the efficacy of the process through which information is transferred within the bank-dominated system of corporate governance. We also found it useful to compare the character of private information disclosures by MG's management (to MG's supervisory board and to Deutsche Bank, respectively) with the disclosures by Enron in its annual reports and other public documents in the early 1990s: Enron's disclosures were more forthcoming.

The MG episode highlights the potential exposure of the Hausbank to moral hazard risks. Based on the now extensive public record, we conclude that Deutsche Bank did not closely monitor the nature and extent of MG's use of Deutsche Bank's financial backing. We appreciate that there is no basis to extrapolate from the MG episode with respect to the quality of monitoring by German banks in general. Nevertheless, the importance of Deutsche Bank's involvement with MG raises questions about the effectiveness of incentives for bank monitoring in cases where smaller amounts could be at risk. ${ }^{9}$ 
Our paper is organized in three sections. Section 1 examines Enron's and MG's trading strategies and character of financial risks inherent in those strategies. The section will consider what risks were foreseeable and how they were to be managed by the two firms.

Section 2 examines what is on the public record concerning communication between (a) MG's management and MG's supervisory board and (b) MG's management and Deutsche Bank. We review the private and public disclosures by the management board with respect to the management of risk exposures undertaken by MG's oil-trading activities and compare them with Enron's public disclosures, which we also examine. We find that MG's public disclosures were limited and less informative then Enron's public disclosures. We also discover that the passage of information from MG's management board to its supervisory board was limited.

The final section (Section 3) sets out a model of how banks are assumed to exercise control over the activities of affiliated nonfinancial firms. We then evaluate how well the model, which focuses on information issues, captures the MG case. Following that, we briefly comment on some of the proposed suggestions for reform in the German system of corporate governance, focusing on those suggestions involving communication of information to the supervisory board.

\section{Section 1: Trading Strategies and Risk Management}

\subsection{Enron}

The strategies of Enron and MG have both been characterized as involving the delivery of financial engineering services to an industry clientele. In the case of Enron, this 
involved creating a "gas bank." ${ }^{10}$ The bank is organized to make long-term, fixed-priced commitments of 15 years or more to both buyers and sellers of natural gas, by contracting for physical gas supplies and obligating itself under gas supply contracts, respectively.

To coordinate its physical product offerings, Enron created a risk management unit. All financial contracting by Enron was the responsibility of this risk management unit. The unit managed Enron's risk exposures by entering into short-term exchange-listed as well as OTC transactions, such as natural gas swaps, with financial firms' commodities groups and traders of physical gas." The maturity of OTC contracts could extend up to 20 years. The unit employed dynamic hedging techniques in its management of the risk exposures of written options positions (caps and floors). These techniques replicate option positions through ongoing adjustments of forward exposures. These adjustments are reflected in variations of counterparty credit exposures.

To manage counterparty risk, Enron created and maintained an independent credit department. Enron outlined its procedures in its annual report and 10-K filings to the SEC. For example, Enron required less than investment-grade firms to post letters of credit or some other collateral to qualify themselves as Enron counterparties. Furthermore, Enron detailed how the firm's accounting recognized its potential exposure to credit losses through charges to current earnings. That is, Enron sought to inform readers of its public disclosures that it was conducting a disciplined trading business in which sources of credit risk were identified and managed.

In Section 2, below, we will discuss the character and the specifics of public disclosures made by Enron. This is done to illustrate what a U.S. firm disclosed in response 
to demands by a dispersed group of financial stakeholders for information about the implementation of a critical trading strategy. Enron's disclosure in its 1993 financial statements reads as if it learned what has come to be regarded as the important lesson of MG for other nonfinancial firms: the disclosure focused on how Enron planned to manage the potentially risky consequences involved in implementing a hedging strategy. ${ }^{12}$

\subsection{MG}

By the late 1980 s, MG had committed to become a player in U.S. oil markets. ${ }^{13}$ At the end of 1991, it began to offer fixed-price contracts to supply heating oil and gasoline with terms of up to 10 years to independent wholesalers and retailers. ${ }^{14}$ Most of the long-term supply contracts were so-called "firm-fixed" and "firm-flexible" contracts, the remainder were guaranteed margin contracts. The guaranteed margin contracts were short-term arrangements that were extendable at MG's discretion. The guaranteed margin contracts did not raise the same kind of risk management issues as the other contracts and thus are not discussed further in this paper.

The firm-fixed contracts required that MG supply end users with a defined total volume for a fixed term at a firm price. As a rule, MG's customers were obligated to accept delivery of an agreed amount of product per month over a 5- or 10-year period. MG has not publicly disclosed how it determined the creditworthiness of purchasers of supply contracts or if it allowed them to qualify as customers through the use of credit mitigants such as letters of credit or collateral. ${ }^{15}$ 
The contract price was to be calculated with reference to a basis that depended on futures contracts maturing within the next 12 months: a simple average of futures prices plus a fixed premium. The firm price quoted did not differ by maturity, that is, the same offered price applied for 5- and 10-year contracts. MG did not offer a rationale for why it chose not to ask for additional compensation for 10-year as opposed to 5-year supply commitments. ${ }^{16}$ Benson offered some commentary on the reason for identical pricing for the two maturities, but his rationale disregarded the consequences of time for valuation and for the computation of future credit exposures. ${ }^{17}$

From mid-1993 on, MG began to offer firm-flexible contracts. Under these contracts, MG entered into long-term delivery commitments for 5 or 10 years at firm prices. But unlike firm-fixed contracts, counterparties had the option of indefinitely deferring (but to no later than the final month of the contract) acceptance of any month's physical delivery. In effect, the firm-flexible contract modified the firm-fixed contract by adding to it an option that permits the purchaser to increase the duration of its contractual obligation to purchase oil. A higher contract price was set by MG for oil delivered under these firm-flexible contracts. Many of the long-term supply contracts included "blow-out" options which allowed the buyer (MG's customer) to close out the contract if the spot price rose to or above the price specified in the supply contract. Under the original firm-fixed contracts, the customers would receive one-half of the difference between the nearest month futures price and the contract price, multiplied by the quantity of undelivered oil; MG would receive the other half. Under the firm-flexible contracts, the customer would receive the entire difference between the 
seconci-rlearesi fuiures price and the contract price, muitipiied by an amount (cnosen by the buyer) not exceeding the volume of undelivered oil under the contract.

In addition, from mid-1993 MG sought to modify existing firm-fixed contracts through the purchase of automatic closeout options from oil buyers. Under this modification, cash settlement would occur automatically once the nearest month futures contract reached an exit price, a strike price above the contract price. The firm-fixed contract customers who accepted this modification were granted concessional discounts on oil to be delivered.

The Special Auditor's Report concluded that MG introduced the firm-flexible contracts partly to improve the 1992/93 fiscal year results of its U.S. operations: "As internal memoranda and descriptions by the management of MGR\&M show, the contractual delivery obligations were expanded between July and September 1993, motivated in part to offset the losses-for accounting purposes, at least-that had already occurred." ${ }^{18}$ In our view, the conclusion is supportable. However, it would be misleading to disregard other aspects of the initiative, namely, with respect to MG's risk exposures. In this respect, it seems plausible to view MG's motives as wanting to create an exposure where the highest payoff would occur if a rise in the price of oil coincided with a persistent reversion of the futures curve to backwardation (negative slope). That is, before the modification (to firm-flexible contracts), profits resulting from the exercise of the blow-out options would not have been dependent upon the slope of the oil futures curve. ${ }^{19}$ (For an outline of MG's basic strategy and examples of possible outcomes under that strategy, see Appendix A.)

An interesting corollary of our proposition that the contractual modifications were designed to rearrange MG's market risk exposures can be deduced. It is that the managers of 
MG's oil trading position revealed no concern about a liquidity constraint. Indeed, in the face of a sharp decline in oil prices and a persistence of contango, MG's U.S. operations required more than $\$ 1$ billion in funding over the fourth quarter of 1993 . More than $\$ 800$ million was accounted for by direct and indirect loans from the German parent firm, with the remainder accounted for by direct bank lending to MG's U.S. subsidiary.

In its March 1995 statement, MG revealed that the Group's financial position had been seriously impaired since September 1991 as a result of a substantial depletion of undisclosed reserves. $^{20}$ Nonetheless, MG was able not only to participate in a substantial volume of onexchange futures transactions involving large variation margin payments, but also transacted a very large volume of OTC swaps. ${ }^{21}$ An obvious question concerns how MG was able to retain its access to financial markets as a borrower and as a counterparty to OTC transactions over a period in which its financial position had become dubious.

The limited evidence available suggests that MG's continued access to financial markets was based on its relationship to Deutsche Bank and Dresdner Bank. Throughout the 1980s, these two banks were consistently involved in arranging and financing MG's program acquisitions. The two banks provided substantial credit (over DM700 million) to MG for these acquisitions. The collaborative nature of their involvement is illustrated by their assistance in MG's takeover of Dynamit Nobel; the assistance included investments by the two banks in shares of the acquired company. ${ }^{22}$ The two banks managed rights issues and equity-related public debt issues for MG in the late 1980s and early 1990s, totaling more than DM 1 billion. $^{23}$ In May 1992, Dresdner Bank received a mandate to arrange a DM1 billion multicurrency credit facility for MG. Two months later, the mandate was revised to a DM1.5 
billion facility involving 46 German and non-German creditor banks. The stated public purpose of the facility was to provide liquidity in support of general corporate operations; however, the Special Auditor's Report refers to an internal MG (parent company) newsletter piece on the facility that mentions its possible use for financing the liquidity needs of MG's oil operations. ${ }^{24}$

MG's new management refers to a December 6, 1993 article in the Frankfurter Allgemeine Zeitung (FAZ) as the first public revelation of its financial difficulties. With the publication of the article, MG's free access to market sources of finance and to transaction counterparties was closed down. (The circumstances and indicators of MG's loss of access to market financing are outlined in Appendix B.) To avoid immediate closeout of its NYMEX positions, MG turned to Deutsche Bank on December 10 for a bridge loan; by the end of December, Deutsche Bank and Dresdner Bank had advanced $\$ 900$ million. ${ }^{25}$ In early 1994, the amount advanced by the two banks was increased to assist in the repayment of over DM800 million of maturing commercial paper. (See Section 3.3, below, for a discussion of the banks' role in MG's financial rescue.) Coincidentally, it was concluded by MG's new management board that the "material adverse change" clause of the 1992 DM1.5 billion credit facility barred MG's drawing on the facility.

The willingness of Deutsche Bank and Dresdner Bank jointly to take the initiative in arranging for emergency bridge lending to $M G$ reflected the presence of their nominees on MG's supervisory board. In turn, the presence accorded a standing under German law that permits banks to act as organizers of financial rescues without undue concern about legal 
risks. By contrast, in the United States, the courts have moved to deter banks from assuming responsibility for rescues of financially troubled corporate clients. ${ }^{26}$

\subsection{Assessment of the Business Plans of Enron and MG}

The business plans of both Enron and MG called for marketing programs of long-term contracts on energy products that depended on active management of market risk exposures through the use of exchange-traded and OTC financial instruments. The plans were both formulated in the period soon after the deregulation of energy prices. In both cases, the business plans were formulated by individuals who anticipated that the market would pay for the intermediation services embedded in long-term fixed-price private sector contracts. The available evidence suggests that Enron's management has implemented a disciplined riskmanagement system that encompasses not only market risk but also credit and liquidity risk. ${ }^{27}$

On the other hand, there are considerable questions concerning MG's approach to the monitoring, measurement and management of financial risks associated with its oil-trading activities. The Special Auditor's Report describes a presentation made by MG's management to MG's supervisory board in January 1993 in which the broad trading strategy was laid out without a detailed discussion of risk management practices. ${ }^{28}$ Reportedly, the discussion was limited to the role of refining capacity in the execution of that strategy as well as a general description of the market risk management strategy to hedge exposure related to supply contracts. In addition, the Special Auditor's Report refers to meetings between Deutsche Bank staff and MG staff in which the hedging strategy was discussed. However, the Special Auditor's Report does not indicate that Deutsche Bank advised MG on the plausibility of 
assumptions embedded in MG's strategy. One conceivable topic of discussion might have been the assumed relationship between the level of the price of oil and the slope of the oil futures term structure. The Special Auditor's Report also does not indicate that MG's managers themselves conducted such evaluations, nor if either the supervisory board or Deutsche Bank had enquired if MG had conducted stress test analyses of the potential consequences of the assumption.

The examination of the MG case by Edwards and Canter (1995) provides us with a summary of analyses discussing the sensitivity of MG's exposures to particular risks. ${ }^{29}$ First, the authors suppose a counterfactual case in which MG had instead chosen to adjust dynamically the hedge ratio of financial contract amounts to physical delivery obligations, as opposed to maintaining the one-to-one hedge ratio (stack hedge). They found that such a minimum-variance hedge would have not allowed MG to benefit as much from rising energy prices or lose as much from falling prices. This analysis produces the assessment that MG assumed greater funding risk and greater rollover risk in exchange for the possibility that it could benefit from higher energy prices. ${ }^{30}$

Edwards and Canter extend their analysis by observing that the magnitude of MG's funding risk associated with a fall in prices would be sensitive to the credit quality of MG's counterparties for supply contracts because of the non-performance risk. This analysis points to the conclusion that the MG management's choices of contractual terms (such as the closeout options) and hedge ratio should have intensified interest among stakeholders in MG for direct information. In the U.S. system, there would be a demand for increased public information, with the stakeholders being responsible for their own evaluation of the 
information on the quality of MG's ability to manage counterparty credit risk. By contrast, it is often said that in the German system, the responsibility is shifted to the Hausbank to acquire and evaluate information on behalf of other stakeholders.

In Section 2, below, we examine the evidence on private and public disclosures by MG and Enron. With respect to MG, no evidence was found of systematic private disclosure of counterparty risk information. By contrast, Enron discloses considerable quantitative and qualitative information on its exposure to counterparty risk and how it manages those exposures with its choice having been, no doubt, influenced by critical public analyses that pointed to the crucial importance of how Enron managed counterparty risk. ${ }^{31}$

\section{Section 2: Public and Private Disclosures}

In recent years, economists have come to recognize the rudimentary state of the economic analysis of institutions. ${ }^{32}$ In response, they have constructed frameworks for thinking about institutions, such as firms. They have concerned themselves with assessing how alternative forms of contractual relationships affect the flow of information between economic agents, the incentives created by such relationships for information flows, and the use of relationship-based information flows to influence or control firm behavior.

One application of the approach concerns the analysis of downstream relationships of banks with nonfinancial firms in various national financial systems. It provides a line of reasoning that has been used to construct a theoretical justification for banks to "control" nonfinancial firms. ${ }^{33}$ 
The case is based on three observations:

(1) Concentration of financial claimholder relationships limits the scope for "free rider" problems. Free rider problems can act as a powerful disincentive to the costly gathering of information and hinder the effective exercise of control. That is, all other things being equal, concentration of financial claims should result in more information being made available to claimholders.

(2) The ability to ensure long-term relationships may be necessary to ensure compensation for the costs incurred in credit evaluation and for the risks associated with the exercise of control in contingencies that could not be fully set out in a contract. That is, a long-term relationship is a necessary condition for a bank to participate willingly in a rescue of a financially troubled customer.

(3) The simultaneous holding of debt and equity can operate to cement long-term relationships and improve the information and control possibilities open to creditors. It should also operate to reduce the scope for conflict between equity and debt holders, especially in situations of financial distress.

The three observations jointly support the case for no constraints on links between banks and nonbank financial firms. They jointly suggest the presumption that Deutsche Bank as MG's Hausbank was well informed about MG's conduct of its oil-trading activities. Conversely, the observations jointly suggest the presumption that Enron's large number of claimholders would not be well informed compared to the standards set in the relationship of Deutsche Bank and MG. In normal circumstances such a comparison would not be possible. However, in the case of MG, the availability of the Special Auditor's Report and other 
sources provided an opportunity for us to assess the process of information transfer that took place between Deutsche Bank and a large corporate customer. The assessment involves comparing the disclosures by Enron and $\mathrm{MG}$ of quantitative and qualitative information on the management of financial risks associated with their trading operations.

\subsection{A Comparison of the Public and Private Disclosures by MG and Enron}

In July 1993, the Group of Thirty published a highly influential report with recommendations for the management of derivatives activities both by derivatives dealers and by end-users. ${ }^{34}$ The report identified basic information needs for monitoring the use of derivatives as: an explanation of the purpose of the transactions, the amounts placed at risk, the character of risks involved, and the accounting treatment.

We constructed an information disclosure framework based on the Group of Thirty's recommendation. In Table 1, we report on Enron's public disclosure of information regarding its risk management activities. Table 1 suggests a substantive enhancement took place in the 1993 financial statements, as compared with 1992. The 1993 statements introduce information on quantitative measures of credit exposures, separating exposures by counterparty types (such as independent power producers; gas and electric utilities; oil and gas producers; industrials; financial institutions; other) as well as into investment-grade and non-investment-grade. In addition, Enron disclosed the amount of reserves that had been set aside to absorb credit losses.

In Table 2, we report on MG's public and private disclosures of information on its derivatives related activities. For public disclosures, we examined the annual reports of MG 
Table 1: Enron's Public Risk Management Disclosure

Type of disclosure

Qualitative disclosures

General explanation of strategy

Discussion of derivatives used in the risk management strategy

Discussion of credit risk

Discussion of policies for limiting risk exposure

Discussion of market risk

Explanation of mark-to-market accounting

\section{Quantitative disclosures}

Nominal derivatives positions

Maturity profile

Estimates of credit exposure in long-term delivery contracts

Reserves for credit risks in longterm delivery contracts

Estimated market value of positions
1992 year-end

financial statements
1993 year-end

financial statements

$\begin{array}{cc}\text { Yes } & \text { Yes } \\ \text { Limited }^{1} & \text { Yes } \\ \text { Yes } & \text { Yes } \\ \text { No } & \text { Yes } \\ \text { No } & \text { Yes } \\ \text { Yes } & \text { Yes }\end{array}$

No

Yes

No Yes

No Yes

No Yes

No Yes

1 Enron's 1992 financial statements discuss the type of instruments used, but provide no information to the extent or manner in which they would assist in the hedging strategy.

Sources: Enron 1992 annual public filing with the SEC (10-K), 1992 annual report; Enron 1993 10-K, 1993 annual report. 


\section{Table 2: Metallgesellschaft's Public and Private Risk Management Disclosure}

\author{
Public disclosure
}

Type of disclosure

Qualitative disclosures

General explanation of strategy

Discussion of derivatives used in the risk management strategy

Discussion of credit risk

Discussion of policies for limiting risk exposure

Discussion of market risk

Explanation of accounting principles
Annual reports

for fiscal years

1990/91, 1991/92
Private disclosure

Disclosure to
supervisory board

Disclosure to

Deutsche Bank

\section{Quantitative disclosures}

Nominal derivatives positions

No

$\mathrm{No}^{2}$

$\mathrm{No}^{3}$

Maturity profile

No

$\mathrm{No}^{2}$

$\mathrm{No}^{3}$

Estimates of credit exposure in

No

$\mathrm{No}^{4}$

$\mathrm{No}^{+}$ long-term delivery contracts

Reserves for credit risk in long-term

No

$\mathrm{No}^{4}$

$\mathrm{No}^{4}$ delivery contracts

Estimated market value of positions

No

No

No

I In its annual report for the fiscal year 1991/92, MG's management board stated that it was using exchange-traded futures to hedge its obligations in long-term delivery contracts. There were no details about the size of the hedging position nor about its maturity profile. There was also no mention of the 


\section{Table 2 (cont.)}

OTC swaps that MG employed as additional hedges. The 1990/91 annual report does not mention the use of futures contracts or swaps as a hedging device.

2 As documented in the Special Auditor's Report, there are conflicting accounts about how much information was passed on by MG's management board to Ronaldo Schmitz, chairman of MG's supervisory board. On January 28, 1993, MG's management gave a presentation on the basic nature of the risk management strategy to the company's supervisory board. However, the Special Auditor's Report states that no details on the hedging strategy were presented. Members of MG's former management claim that Schmitz was fully informed of almost all details of the risk management strategy at later dates, such as the use of futures hedging, the risks inherent in the long-term contracts, the assumption of backwardation, and liquidity risk. Schmitz claims that he was briefed only on the basic concepts.

3 In this case, the Special Auditor's Report again states that there are conflicting accounts about the transfer of information from MG's management board to Deutsche Bank, in the case when the latter acted as MG's business partner for the proposed marketing of risk management products. At a meeting with the Deutsche Bank Liquidity Group on November 23, 1992, MG staff outlined the risk management strategy and some of its assumptions, including backwardation. Ronaldo Schmitz was present at this meeting, acting not as supervisory board chair of MG, but as a member of the Deutsche Bank Liquidity Group. As the Special Auditor's Report documents, former MG staff claim that on other occasions during the course of 1992 Deutsche Bank personnel were given a complete explanation of the delivery contracts. Deutsche Bank personnel, on the other hand, claim that MG staff were reluctant to disclose details of the contracts and the risks contained therein. The Special Auditor's Report notes that MG sent copies of the long-term delivery contracts separately to MG's legal department and to Deutsche Bank's legal department for review.

4 Based on the information contained in the Special Auditor's Report, there is no evidence that MG staff provided the supervisory board or Deutsche Bank with quantitative information on credit risk.

Sources: Special Auditor's Report; MG 1990/91 annual report; MG 1991/92 annual report. 
for the following fiscal years: 1990/91, 1991/92, 1992/93. The last of these three reports was released in February, 1994 and included revised results for the fiscal year 1992/93 and a brief discussion by MG's new management board acknowledging that losses had been incurred by MG's U.S. oil operations. ${ }^{35}$ We also reviewed the next two MG annual reports (not reflected in Table 2). The report for the fiscal year ending September 30, 1994 provided more qualitative information concerning MG's use of derivatives. Finally, the annual report for the year ending September 30, 1995 introduces quantitative information in MG's public disclosures.

The limited amount of public disclosure by MG concerning its use of derivatives to conduct risk management did not surprise us. What was surprising was that private disclosures (to MG's supervisory board and to Deutsche Bank, as outlined in the Special Auditor's Report) by the management board were only somewhat more informative than its public disclosures: the private disclosures did not provide useful information concerning MG's risk management activities and fared poorly in comparison with Enron's contemporary public disclosures. ${ }^{36}$ Indeed, Ronaldo Schmitz has confirmed our finding in a recent statement that the reporting by MG's management board has been reformulated under the new management board to improve the quality and timeliness of information passed on to the supervisory board. ${ }^{37}$

In summary, the information developed in this section supports the view that there was limited interest on the part of stakeholders in MG to encourage the management to be more forthcoming in both public and private disclosures. By contrast, in Enron's case, the enhancement of disclosure coincided with greater public interest in firms' use of derivatives, in general, and in Enron's involvement, in specific. 


\section{Section 3: Incentives and Disincentives to Monitor}

A number of information-based activities have been identified as possible sources of competitive advantage for banks to serve as financial monitors of other firms. These include:

(a) collecting information on firms' ongoing operations;

(b) offering informed advice to firms' managements concerning the formulation and execution of business strategies;

(c) making informed judgements on managerial performance; and

(d) communicating well-informed signals to other potential creditors of the firm.

\subsection{Monitoring Ongoing Operations}

Under German law, supervisory board members must treat information received from a firm's management as confidential. A supervisory board member who is a bank's nominee is also not permitted to pass on bank-confidential information to a firm's management, including confidential information on that same firm. ${ }^{38}$ In connection with supervisory board service, the member may tap into the bank's areas of technical expertise.

The information that we reviewed certainly does not suggest that Deutsche Bank was well informed about MG's oil-trading operations simply because its nominee served as chair of MG's supervisory board. We also did not find evidence that the supervisory board requested information from MG's management based on well-informed questions passed by Deutsche Bank to its supervisory board nominee. For example, MG's increased use of credit facilities for the hedging strategy was not cited by the Special Auditor's Report as a topic discussed by the supervisory board. However, based on the available information, we cannot choose between two 
hypotheses concerning such behavior, namely, that German legal prohibitions were effective or that bank nominees on supervisory boards have little incentive to be actively involved in the oversight of the ongoing operations of firms.

Evidence in a recent paper by Steven Kaplan supports the hypothesis of limited involvement by supervisory boards in the management of German firms. ${ }^{39}$ Kaplan finds that the replacement of German managers is influenced by stock market outcomes in much the same manner as in the United States. This suggests that German supervisory boards use the same sort of open-market price signals as available to U.S. boards of directors, rather than process private information. ${ }^{40}$

On the other hand, it is informative to review the supervisory board's response to the receipt of a special audit of MG by KPMG in mid-December 1993, in the wake of the appearance of press reports that raised concerns about MG's NYMEX trading positions. ${ }^{41}$ The supervisory board responded to the loss revelations by replacing MG's management board. The new management board then asked Deutsche Bank and Dresdner Bank, both with representatives on MG's supervisory board, to assist in organizing a creditors' coordinating committee, which Deutsche Bank chaired. This creditors' committee, in turn, considered a rescue plan put forward by MG's new management. ${ }^{42}$

Theodor Baums has drawn a picture of active involvement by bank nominees on supervisory boards. ${ }^{43}$ He suggests that they provide banks' client firms with specialized advice, financial knowledge, and information. He buttresses his case by noting that: "Large banks have departments specialized in corporate finance, analyzing financial markets as well as the financial needs of their clients." 44 However, in our review, we found no evidence of an information flow 
to the supervisory board from the bank representatives with suggestions for the conduct of MG's oil trading operations. ${ }^{45}$ In particular, there is no information on MG's management being advised by the supervisory board or by one its bank shareholders to modify its hedging strategy so as to conserve scarce short-term funding capacities.

On the other hand, ex post, Ronaldo Schmitz critically discussed MG's operations, including its management of credit and liquidity risk. ${ }^{46}$ His discussion focused on four issues: (1) the creditworthiness of MG's customers, (2) the management of MG's liquidity position, (3) the exit options, and (4) the character of German accounting methods.

With respect to the creditworthiness of MG's customers, Schmitz commented that 200 of MG's customers were middle-sized firms whose likely default had not been considered by MG. He noted that the default risk had been taken into account upon the reorganization of MG's oiltrading business in late December 1993. We take this comment as an indicator of Schmitz's heightened awareness of MG's risk management activities in his role as MG's supervisory board chairman; in addition, Schmitz's comments could be representative of a new sensitivity on the part of bank nominees serving on supervisory boards.

Schmitz commented that it was his judgement that MG should not draw on its back-up credit facility. This is because such a drawing would have violated the facility's clause that drawing should not take place if there had been a material deterioration in business health. He acknowledged that this decision triggered the need for Deutsche Bank and Dresdner Bank to set up the emergency credit facility in December 1993. On the other hand, he was not forthcoming about the possible legal risks associated with a violation of the negative pledge clauses contained in the 1992 back-up credit facility through the collateralization of the emergency credit facility. 
Schmitz alluded to the technical problems involved in hedging the exit options. In particular, he focused on the technical problems raised by firm-flexible contracts. The Special Auditor's Report contains no evidence that the supervisory board routinely reviewed the specifics of contracts offered by MG prior to December 1993.

Finally, Schmitz argued that German accounting methods had not misled the supervisory board. ${ }^{47}$ Schmitz mentioned his concurrence with KPMG's decision to apply value adjustments that had resulted in oil derivatives-related losses of $\$ 800$ million. Schmitz's statement can be taken as an indication of his post-crisis command of the MG situation.

In summary, Schmitz's comments about the obvious deficiencies of the MG operation, if they are taken at face value, point to an absence of his active involvement as a financial advisor of MG during 1993. That is, Schmitz's involvement with MG is not of the character described by Baums.

\subsection{Signalling}

It has been argued that a firm can benefit from being identified as a client of a bank, in the sense that such involvement labels the firm as a "good credit risk." The presumption is that such identification is enhanced if the bank is directly involved in the governance of the firm. In the case of MG, a number of parties may have chosen to act as if MG were backed by Deutsche Bank and that the bank actively monitored MG's operations. ${ }^{48}$ One possible instance where such an assumption played a role is NYMEX's authorization of higher limits for MG at the end of 1992, even though NYMEX had concluded as early as September 1992 that MG's NYMEX member was insufficiently capitalized. ${ }^{49}$ 
Based on the evidence presented in this paper, financial market participants might have reason for concern about the performance of German banks as financial advisers in normal circumstances. But it is not clear that market participants have been as much concerned with this performance as opposed to the performance of German banks with respect to financially troubled customers. It is widely accepted that German banks will assume responsibility for the refinancing of financially troubled customers. In the MG case the major German banks did play this role; nevertheless, there were expressions of dissatisfaction among other creditors. This suggests that it might be revealing to compare the structure of the proposed financial rescue with the structure that was finally negotiated.

\subsection{The Financial Rescue}

In the aftermath of the public disclosure about MG's losses from its oil-trading operations, Deutsche Bank and Dresdner Bank participated in a restructuring of MG. Table 3 outlines the structure of the DM3.4 billion financial rescue originally proposed on January 6 , 1994 and also the structure accepted on January 15, 1994, including subsequent amendments (added through March 1995).

The sizeable discrepancy between the structure of the proposed rescue and of the agreed rescue indicates that the German shareholder banks did not impose a solution on other creditors. ${ }^{50}$ The agreed solution required the German bank shareholders to purchase convertible shares from other creditor banks and to increase their percentage of MG's shares outstanding to over 27 percent as compared with less than 23 percent before the rescue. 


\section{Table 3: The Financial Rescue of MG}

The MG financial rescue plan that was proposed on January 6, 1994 consisted of three main parts:

(A) a conversion of DM1.3 billion worth of bank debt into convertible profit-sharing certificates;

(B) a DM1.4 billion capital increase:

(C) a credit line of DM500 million.

Proposed rescue (January 6,1994$)$

Shareholder
banks
(Deutsche Bank
and Dresdner
Bank)

(A) set to convert existing bank debt into convertible certificates.

(B) set to participate in new share offering proportional to MG share capital held (Deutsche 10.65 percent ${ }^{\prime}$, Dresdner 12 percent).

(C) no participation in DM500 million line of "new money" credit.'

Other creditor banks ${ }^{4}$

\section{Non-bank shareholders}

(A) set to convert existing bank debt into convertible certificates.

(B) to purchase 38 percent of new share offering.

(C) set to provide entire DM500 million in new credit.

(B) major shareholders (including the Investment Office of Kuwait, Allianz, and Daimler-Benz) set to participate in proportion to MG share capital held. Together with Deutsche and Dresdner, these major shareholders would assume 62 percent of the capital increase.

\author{
Agreed rescue (January 15, 1994) \\ and subsequent amendments
}

(A) agree to assume an additional DM50 million each from other creditor banks' positions.

In March 1995, Deutsche and Dresdner paid between DM100-200 million to buy out the positions of 12 foreign creditor banks.

(B) agree to increase participation (Deutsche 16.6 percent of new share offering, Dresdner 17.2 percent of new share offering). ${ }^{3}$

(C) agree to provide DM150 million each for line of credit. raised to DM700 million (see (B) under "Other creditor banks").

(A) some creditor banks (including non-German banks) negotiate arrangements to reduce their participation in bank debt conversion; Deutsche and Dresdner agree to make up the difference (DM100 million).

In March 1995, 12 foreign banks sell their positions to Deutsche and Dresdner for DM100-200 million.

(B) smaller participation in new share purchase.

(C) scale back participation in credit line from DM500 million to DM400 million (new money).

(B) major shareholders agree to original plan; small shareholders given the choice to maintain their relative share of MG capital via a rights issue.

In May 1994, MIM Holdings (Australia) sold its 3.5-percent stake in MG.

\footnotetext{
I Reflects only Deutsche Bank's ownership in a joint trust with Allianz.
} 


\section{Table 3 (cont.)}

2 The two banks noted that they had jointly extended DM1.5 billion through a secured bridge loan in December 1993.

${ }^{3}$ As of March 1995, Deutsche Bank had increased its stake in MG to 13.1 percent, Dresdner Bank to 14.2 percent.

4 There were 120 creditor banks, including 10 German banks, as well as French, British, Swiss, Dutch, Canadian, Italian, and American banks. Holders of MG commercial paper did not take part in the restructuring, but were reportedly paid off with proceeds of new-money credit.

Sources: Börsen-Zeitung, Frankfurter Allgemeine Zeitung, Financial Times, and other periodicals. 
It is impossible for us to assess whether the two shareholder banks paid too high a price for securing agreement to the MG rescue. But the fact that there were disputes about the financing structure should be of no surprise in light of the diversification of financial relationships of Germany companies. This outcome is in line with a basic point in a recent paper by Bolton and Scharfstein which is that the structure of debt affects the negotiations that follow recognition of financial problems. ${ }^{51}$ They demonstrate that negotiation of outcomes can be affected by the number of creditors, the distribution of security interests in specific assets, and by the character of voting rules.

In summary, the MG case and its aftermath raise questions about the sustainability of traditional German financial restructuring techniques in the presence of passive monitoring by supervisory boards. The questions arise due to the increasing interest of managements of major German firms to establish and maintain more complex financial relationships, and to have these relationships with a larger and more diverse group of creditors.

\subsection{Reforms}

The MG case has raised different issues on the two sides of the Atlantic. In the United States, MG was viewed as another instance of sizeable losses associated with derivatives trading. In Germany, the MG case led to renewed interest in German corporate governance and calls for reform. Our paper was primarily motivated by the second set of issues and we comment on two proposed sets of reforms.

One proposed set of reforms focuses on improving information flows to the supervisory board, for example, to enhance the responsibility and independence of firm 
auditors. ${ }^{52}$ The auditors would be charged to keep the supervisory board sufficiently well informed so that it can provide ongoing oversight of management. Related proposals call for the creation of audit committees by supervisory boards. The committees would presumably force supervisory board members to spend more time examining a firm's risk management strategies and controls. A second set of reforms aims at improving accountability to shareholders by reducing or removing the ability of banks to vote the proxies of nonbank shareholders. Advocates of such reforms, e.g., the German Shareholders Association, view them as a means of encouraging supervisory board accountability to shareholders.

The two sets of reforms differ in how they would "fix" the German system of corporate governance. The first emphasizes enhancing resources available to the supervisory board. For example, advocates of this approach could well argue that independent auditors with broadened mandates would have scrutinized the MG trading strategy; such scrutiny might well have led the supervisory board to examine critically MG's proposed trading strategy. On the other hand, the second set of reforms places particular emphasis on correcting conflicts of interest that supposedly permeate German bank relationships with their corporate customers.

\section{Concluding Remarks}

The objective of this paper is not to add to the voluminous amount already written on MG's oil trading activities. Instead, we have viewed the incident as providing us with source material on how the German corporate governance system functions. We are sensitive to the fact that the case presented might not be representative. However, the size of MG and the 


$$
-30 \text { - }
$$

size of bank stakes in MG suggest that the relationship was sufficiently important to merit attention.

The evidence referenced in this paper points to the conclusion that although two major German banks had sufficient financial interests in MG, they were not well informed about the implementation of an oil-trading strategy that almost bankrupted the firm. This aspect of the MG case demonstrates why there might well be reservations about overwhelming reliance on the transmission of private information: a supposedly key component of the German model of corporate governance. 


\section{Notes}

1. See Shleifer, Andrei and Robert W. Vishny (1996), "A Survey of Corporate Governance," NBER Working Paper 5554, April; and Roe, Mark (1993), "Some Differences in Corporate Structure in Germany, Japan, and the United States," The Yale Law Review, 102, June.

2. See Gorton, Gary and Frank A. Schmid (1996), "Universal Banking and the Performance of German Firms," January (in process).

3. MG Corp. is the parent of MG Refining and Marketing, Inc., the firm that actually conducted the oil-trading activities from offices in Bel Air, Maryland. To simplify the discussion, we refer to MG rather than specific member firms of the $M G$ group.

4. Large German companies are required to have a two-tiered board system of corporate governance. The upper tier, the supervisory board (Aufsichtsrat) is made up in equal share of representatives of the shareholders and labor; these representatives designate a chair. The supervisory board appoints management and votes on strategic issues. The management board (Vorstand), or lower tier, is responsible for day-to-day management of the company.

5. Detailed information on the structure of sharehoildings in MG prior to the rescue can be found in "Rücktritte fällig," Wirtschaftswoche, January 14, 1994, p. 36.

6. In the early 1980s, MG paid no dividend for three straight fiscal years. Dividend payments were resumed after the fiscal year 1984/85, and by the fiscal year $1989 / 90$ had increased by over 60 percent to DM 10 per share. After the fiscal year 1991/92, the dividend was cut 20 percent.

7. A discussion of Benson's employment history with MG can be found in an arbitration board's opinion on MG's case against Benson and his son (American Arbitration Association \#13-116-371-94, May 2, 1996). Benson was first employed by MG in mid-1987. According to the arbitrators, Benson left a year later despite strenuous efforts by the head of MG's management board, Heinz Schimmelbusch, to retain him. He returned to MG in November 1991. Benson was fired on February 4, 1994, less than two months after MG's CEO (Schimmelbusch) and CFO (Forster) were dismissed by the supervisory board (on December 17, 1993). The head of MG Corp., Siegfried Hodapp, had resigned just prior to the dismissal of Schimmelbusch and Forster.

8. The supervisory board chairman is responsible for passing information from the management to the other supervisory board members.

9. One quantitative indicator of what was at stake for Deutsche Bank is the size of its shareholding in MG, with a market value of approximately DM320 million as of September 30, 1993.

10. Bhatnagar, Sanjay and Peter Tufano (1995), "Enron Gas Services," Harvard Business School Case Study (9-294-076), September.

11. The natural gas contract on the New York Mercantile Exchange (NYMEX) first traded in June 1990. Futures contracts extend for maturities of 18 months or less. 
12. Antonio Mello and John Parsons model how liquidity and cash flow timing problems associated with different hedging strategies can influence firm valuation. See Mello, Antonio S. and John E. Parsons (1995), "Funding Risk and Hedging Valuation," a paper prepared for INQUIRE Europe 5th Anniversary Seminar, October.

13. For background material on MG's trading strategy we relied on "The Mastering of a Crisis", a booklet published by MG's management board in March, 1995 and the Bericht über die Sonderprüfung nach § 142 Abs. I Aktiengesetz of C\&L Treuarbeit Deutsche Revision, Wollert-Elmendorff Deutsche Industrie-Treuhand GmbH, January 1995 (hereinafter referred to as the "Special Auditor's Report"). The Special Auditor's Report was commissioned by the Extraordinary Shareholders Meeting of Metallgesellschaft AG of February 24, 1994. Any direct quotes from the Special Auditor's Report are the authors' translation.

14. Some accounts have suggested that MG had investment grade counterparties and did not deal just with "truck stop" operators. The dispute concerning the "true" mix of MG's counterparties persists because MG did not make credit risk information available.

15. The Special Auditor's Report has no discussion of how MG managed its credit exposures associated with its oil trading activities.

16. MG not only assumed long-term credit exposures, but also sizeable regulatory exposures through its commitments to deliver petroleum of a constant quality in the face of possible costly mandates.

See discussion in "The Mastering of a Crisis," p. 7.

17. Benson believed that the longer-term risk of the 10-year contract could be offset by the arbitrage gains over the longer maturity. See Special Auditor's Report, p. 33.

18. Special Auditor's Report, p. 50. See also Appendix 9 of the Special Auditor's Report.

19. The modification is consistent with statistical test results that are highly significant and document a strong negative relation between oil futures prices and the slope of the futures curve. See Ross, Stephen A. (1996), "Hedging Long-Run Commitments: Exercises in Incomplete Market Pricing," May (in process).

20. "The Mastering of a Crisis," p. 13.

21. MG's losses due to payment of variation margin reflected transactions on exchanges as well with OTC counterparties. In the swap transactions, counterparties dealt with MG bilaterally and, in turn, presumably took offsetting positions in exchange-traded contracts. It is possible that a portion of MG's involvement in OTC contracts was prompted by NYMEX limits.

22. Press accounts mention the involvement of Ronaldo Schmitz in MG's 1992 acquisition of Feldmühle Nobel. Schmitz, a member of Deutsche Bank's managing board, became a member of MG's supervisory board in 1992 and the chairman of MG's supervisory board in 1993.

23. In addition, the two banks assisted MG with sales of minority interests in some of its subsidiaries, such as Buderus, Kolbenschmidt, and Berzelius-Umwelt-Service (B.U.S.), totaling no less than DM 500 million. 
24. For a discussion of the newsletter piece see the Special Auditor's Report, p. 54. We reviewed press discussions of the credit facility and found no mention of MG's oil operations. The absence of references suggests that the internal MG assessment of a need to provide for possible liquidity demands was not disseminated in the markets by either MG or Dresdner Bank.

25. The loan was secured by shares in two MG subsidiaries, Buderus and Dynamit Nobel.

26. The concept of equitable subordination under U.S. law permits a court to impose a penalty on a bank for the exercise of control over a debtor firm. The penalty may be a significant reduction in the priority status of a bank's claims. For a discussion of the interplay of banking structure and bankruptcy law, see Frankel, Allen and John Montgomery (1991), "Financial Structure: An International Perspective," Brookings Papers on Economic Activity, No. 1.

27. In February 1993, Risk magazine (a trade periodical) listed Enron among the top firms dealing in commodity derivatives. In fact, Enron was ranked as the top firm in short-term natural gas swaps, in long-term natural gas swaps, and in exotic products/structured transactions.

28. Special Auditor's Report, pp. 163-167.

29. Edwards, Franklin R. and Michael S. Canter (1995), "The Collapse of Metallgesellschaft:

Unhedgeable Risks, Poor Hedging Strategy, or Just Bad Luck?," Journal of Futures Markets, Vol. 15, No. 3, pp. 211-264.

30. Ross (op. cit.) provides an analytic result, and confirming evidence from simulations, that alternative strategies dominate stack hedges. However, his discussion suffers in that it treats MG's blow-out options separate from its other trading activities.

31. In a May 23, 1993 Forbes article entitled "Hidden Risks," Toni Mack raised questions about the exposure of Enron to performance failures by its suppliers, customers and financial counterparties. The first critical public discussions of MG's credit management did not appear until early 1994 as background material for ex post discussions of the decision by MG's new management to terminate supply contracts unilaterally.

32. See Hart, Oliver (1995), Firms, Contracts and Financial Structure, Oxford University Press.

33. See discussion of information/control efficiencies in Borio, Claudio E.V. and Renato Filosa, (1994), "The Changing Borders of Banking: Trends and Implications," a paper prepared for a meeting of the Associazione Nazionale per lo Studio dei Problemi del Credito, revised, October.

34. Group of Thirty (1993), Derivatives: Practices and Principles, Global Derivatives Study Group.

35. Table 2 does not reflect disclosures from MG's $1992 / 93$ annual report because that annual report was released after MG's financial difficulties had become public knowledge.

36. Subsequently, Enron has modified its disclosures in response to changes in financial accounting standards as well as in response to developments in the standard risk management practices of financially active firms. 
37. Deutsche Schutzvereinigung für Wertpapierbesitz (1995), Aufsichtsräte in Deutschland, Verlag Das Wertpapier, p. 66.

38. Cbviousiy, a bank acting as a creditor to a firm may request and evaluate information from the firm. However, this information should not be passed through the bank's representative on the supervisory board. That is, German law creates a "Chinese Wall" concept governing the relations between a bank with a supervisory board seat and the bank's client firm.

39. Kaplan, Steven N. (1994), "Top Executives, Turnover and Firm Performance in Germany," Journal of Law, Economics and Organization. Vol. 10, pp. 142-159.

40. In the case of MG, it is worth noting that the contract of the head of the management board, Heinz Schimmelbusch, was extended for another 5-year term on November 19, 1993. The contract renewal took place less than a month before his dismissal by the supervisory board.

41. In July 1993, Ronaldo Schmitz had asked that an audit be conducted of MG's U.S. operations, particularly as they relate to derivatives. According to the Special Auditor's Report, the KPMG audit was completed in mid-November 1993, but only handed over to Schmitz on December 8, 1993.

42. Public sources are not clear on the roles played by Deutsche Bank and Dresdner Bank in other matters pertaining to MG's restructuring, such as the decision to terminate supply contracts unilaterally, made in mid-December 1993.

43. Baums, Theodor (1994), "The German Banking System and its Impact on Corporate Finance and Governance," in The Japanese Main Banking System, edited by M. Aoki and H. Patrick.

44. Op. cit., p. 433.

45. The Special Auditor's Report (p. 173) mentions that, in 1992, MG corporate customer contracts were reviewed both by MG's and Deutsche Bank's legal departments so as to conform with German law. The review was undertaken to analyze a possible joint venture in which Deutsche Bank would market MG's risk management services to its German customers. The Special Auditor's Report description does not refer to any communication between the two legal departments. Deutsche Bank's interest in a joint venture is likely attributable to German banking regulations that prohibit German banks from dealing in commodities.

46. In 1994, a number of studies appeared that critically examined the strategic choices made by MG, including the decision to cancel customer contracts with positive replacement values unilaterally.

Börsen-Zeitung, a prominent German financial daily, published an interview with Ronaldo Schmitz on September 27, 1994 in which Schmitz commented on the findings of Merton Miller and other academic commentators. See, for example:

- Culp, Christopher and Merton Miller (1994), "Hedging a Flow of Commodity Deliveries with Futures: Lessons from Metallgesellschaft." Derivatives Quarterly, September, pp. 7-15;

- Culp and Miller (1995a), "Metallgesellschaft and the Economics of Synthetic Storage." Journal of Applied Corporate Finance, Winter, pp. 62-76;

- Culp and Miller (1995b), "Auditing the Auditors." Risk, April, pp. 36-39;

- Culp and Miller (1995c), "Basis Risk and Hedging Strategies: Reply to Mello and Parsons."

Derivatives Quarterly, Summer, 20-26. 
47. For a description of this debate, see:

- Edwards, Franklin (1995), "Derivatives Can Be Hazardous to Your Health: The Case of Metallgesellschaft," Derivatives Quarterly, Vol. 1, Spring, pp. 8-17;

- Culp, Christopher and Merton Miller (1995a), "Metallgesellschaft and the Economics of Synthetic Storage," Journal of Applied Corporate Finance, Vol. 7, Winter, pp. 62-76;

- Mello, Antonio and John Parsons (1995b), "Rolling the Dice," Risk. May, pp. 49-50.

48. In various analyses of MG, a number of authors (most prominently Merton Miller) have asserted that financing of MG should not have been a question because of the backing of Deutsche Bank. In his discussions of Miller's analysis, Schmitz chose to ignore the issue of Deutsche Bank's backing of MG. See Börsen-Zeitung (op. cit.).

49. Special Auditor's Report, p. 51.

50. Approximately one year after the MG rescue, Deutsche Bank stepped in to assist another client firm in which it held a significant stake, Klöckner-Humboldt-Deutz (KHD), a machinery manufacturer. Deutsche Bank ended up providing DM430 million of the over DM700 million rescue package, in addition to abandoning claims of DM150 million on KHD. Press commentary suggests that Deutsche Bank was forced to take on a larger share of the rescue package during negotiations with other creditor banks, both German and non-German. (See Börsen-Zeitung, January 31, 1995, and February 9, 1995). In May 1996, previously undisclosed losses at KHD were recognized, initiating negotiations between KHD's management board and Deutsche Bank regarding a new round of financial restructuring. (Of note is that Deutsche Bank holds 48 percent of KHD's equity capital, and the bank's management board chairman, Hilmar Kopper, served as the head of KHD's supervisory board until last year.) On June 5, KHD's management announced that its creditors had agreed to a rescue package of DM1 billion, DM550 million of which Deutsche Bank will contribute.

51. Bolton, Patrick and David S. Scharfstein (1996), "Optimal Debt Structure and the Number of Creditors," Journal Of Political Economy, pp. 1-25.

52. The German Shareholders Association (Deutsche Schutzvereinigung für Wertpapierbesitz) published a book in 1995 (op. cit.) that outlined possible reforms for supervisory boards. The book included commentary on the Association's proposals by a number of supervisory board members-representatives of banks and industrial firms--including Ronaldo Schmitz. See also Götz, Heinrich (1995), "Die Überwachung der Aktiengesellschaft im Lichte jüngerer Unternehmenskrisen," Die Aktiengesellschaft. August. 


\section{References}

American Arbitration Association (1996), Ruling \#13-116-371-94, May 2.

Baums, Theodor (1994), "The German Banking System and its Impact on Corporate Finance and Governance," in The Japanese Main Banking System, edited by M. Aoki and H. Patrick.

Baums, Theodor (1995), "Universal Banks and Investment Companies in Germany," paper given at Conference on Universal Banking at New York University Stern School of Business, February 23-34.

Benson, W. Arthur (1994), complaint filed against MG Corp and MG R\&M, February 28.

Bhatnagar, Sanjay and Peter Tufano (1995), "Enron Gas Services," Harvard Business School Case Study (9-294-076), September.

Bolton, Patrick and David S. Scharfstein (1996), "Optimal Debt Structure and the Number of Creditors," Journal of Political Economy, pp. 1-25.

Borio, Claudio E.V. and Renato Filosa (1994), "The Changing Borders of Banking: trends and implications," a paper prepared for a meeting of the Associazione Nazionale per lo Studio dei Problemi del Credito, October.

C\&L Treuarbeit Deutsche Revision and Wollert-Elmendorff Industrie Treuhand (1995a), Bericht über die Sonderprüfung nach $\$ 142$ Abs. I Aktiengesetz, February 6.

C\&L Treuarbeit Deutsche Revision and Wollert-Elmendorff Industrie Treuhand (1995b), "Stellungnahme zur Erwiderung von Frau Dr. Cindy Ma," March 20.

Cooper, Ian, and Antonio Mello (1996), "Optimal Use of Forward Contracts with Default Risk," working paper, February.

Culp, Christopher and Miller (1994), "Hedging a Flow of Commodity Deliveries with Futures: Lessons from Metallgesellschaft," Derivatives Quarterly, Vol. 1, September, pp. 7-15.

Culp and Miller (1995a), "Metallgesellschaft and the Economics of Synthetic Storage," Journal of Applied Corporate Finance, Vol. 7, Winter, pp. 62-76.

Culp and Miller (1995b), "Auditing the Auditors," Risk, April, pp. 36-39.

Culp and Miller (1995c), "Basis Risk and Hedging Strategies: Reply to Mello and Parsons," Derivatives Quarterly, Summer, pp. 20-26.

Deutsche Schutzvereinigung für Wertpapierbesitz (1995), Aufsichtsräte in Deutschland, Verlag Das Wertpapier. 
Edwards, Franklin (1995), "Derivatives Can Be Hazardous to Your Health: The Case of Metallgesellschaft," Derivatives Quarterly, Vol. 1, Spring, pp. 8-17.

Edwards, Franklin, and Michael S. Canter (1995), "The Collapse of Metallgesellschaft: Unhedgeable Risks, Poor Hedging Strategy, or Just Bad Luck?," Journal of Futures Markets, Vol. 15, no. 3, pp. 211-264

Edwards, Jeremy, and Klaus Fischer (1994), Banks, Finance, and Investment in Germany, Cambridge University Press.

Enron Corp, 1992 annual report, 1993 annual report, 1992 10-K, 1993 10-K, 1994 10-K, 1995 10-K.

Falloon, William (1994), "MG's Trial by Essay," Risk, October, pp. 28-34.

Frankel, Allen and John Montgomery (1991), "Financial Structure: An International Perspective," Brookings Papers on Economic Activity, No. 1.

Gorton, Gary and Frank A. Schmid (1996), "Universal Banking and the Performance of German Firms," January (in process).

Götz, Heinrich (1995), "Die Überwachung der Aktiengesellschaft im Lichte jüngerer Unternehmenskrisen," Die Aktiengesellschaft. August.

Grant, Dwight (1984), "Rolling the Hedge Forward: An Extension," Financial Management, Winter 1984.

Group of Thirty (1993), Derivatives: Practices and Principles, Global Derivatives Study Group.

Hart, Oliver (1995), Firms, Contracts and Financial Structure, Oxford University Press.

Hilliard, Jimmy (1995), "Analytics Underlying the AG Metallgesellschaft Hedge: Short Term Forwards in a Multi-Period Environment," March.

Hutchinson, Michael Jr. (1994), "The Metallgesellschaft Affair: Risk Management in the Real World," October.

Kaplan, Steven N. (1994), "Top Executives, Turnover and Firm Performance in Germany," Journal of Law, Economics and Organization, Vol. 10, pp. 142-159.

Kropp, Mattias (1995) "Die Öltermingeschäfte der Metallgesellschaft -- Anmerkungen zu einer Kontroverse," Zeitschrift für Bankrecht und Bankwirtschaft, February 28, pp. 14-32.

Litzenberger, Robert, and Nir Rabinowitz (1995), "Backwardation in Oil Futures Markets: Theory and Empirical Evidence," Journal of Finance, Vol. L, No. 5, December, pp. 1-29.

Mack, Toni (1993), "Hidden Risks," Forbes, May 23, p. 54. 
Mello, Antonio, and John Parsons (1995a), "Maturity Structure of a Hedge Matters: Lessons from the Metallgesellschaft Debacle," Journal of Corporate Finance, Spring, pp. 106-20.

Mello and Parsons (1995b), "Rolling the Dice," Risk. May, pp. 49-50.

Mello and Parsons (1995c), "Hedging a Flow of Commodity Derivatives with Futures: Problems with a Rolling Stack," Derivatives Quarterly, Summer, pp. 16-19.

Mello and Parsons (1995d), "Funding Risk and Hedge Valuation," working paper, October.

Mello and Parsons (1996), "When Hedging Is Risky: An Example," working paper, March.

Metallgesellschaft AG (1995), "The Mastering of a Crisis," March.

Metallgesellschaft AG, Annual Reports 1990/91, 1991/92, 1992/93, 1993/94.

Neuberger, Anthony (1995), "How Well Can You Hedge Long Term Exposures with Multiple Short Term Futures Contracts?," working Paper \# 214-195, Institute of Finance and Accounting, London Business School, July.

Ross, Stephen A. (1996), "Hedging Long-Run Commitments: Exercises in Incomplete Market Pricing," May (in process).

Roe, Mark (1993), "Some Differences in Corporate Structure in Germany, Japan, and the United States," The Yale Law Review, 102, June.

Shleifer, Andrei and Robert W. Vishny (1996), "A Survey of Corporate Governance," NBER Working Paper 5554, April.

U.S. Commodity Futures Trading Commission (1995), "CFTC Order to Impose \$2.25 Million Civil Penalty Against MG Refining and Marketing, Inc. and MG Futures, Inc.," July. 


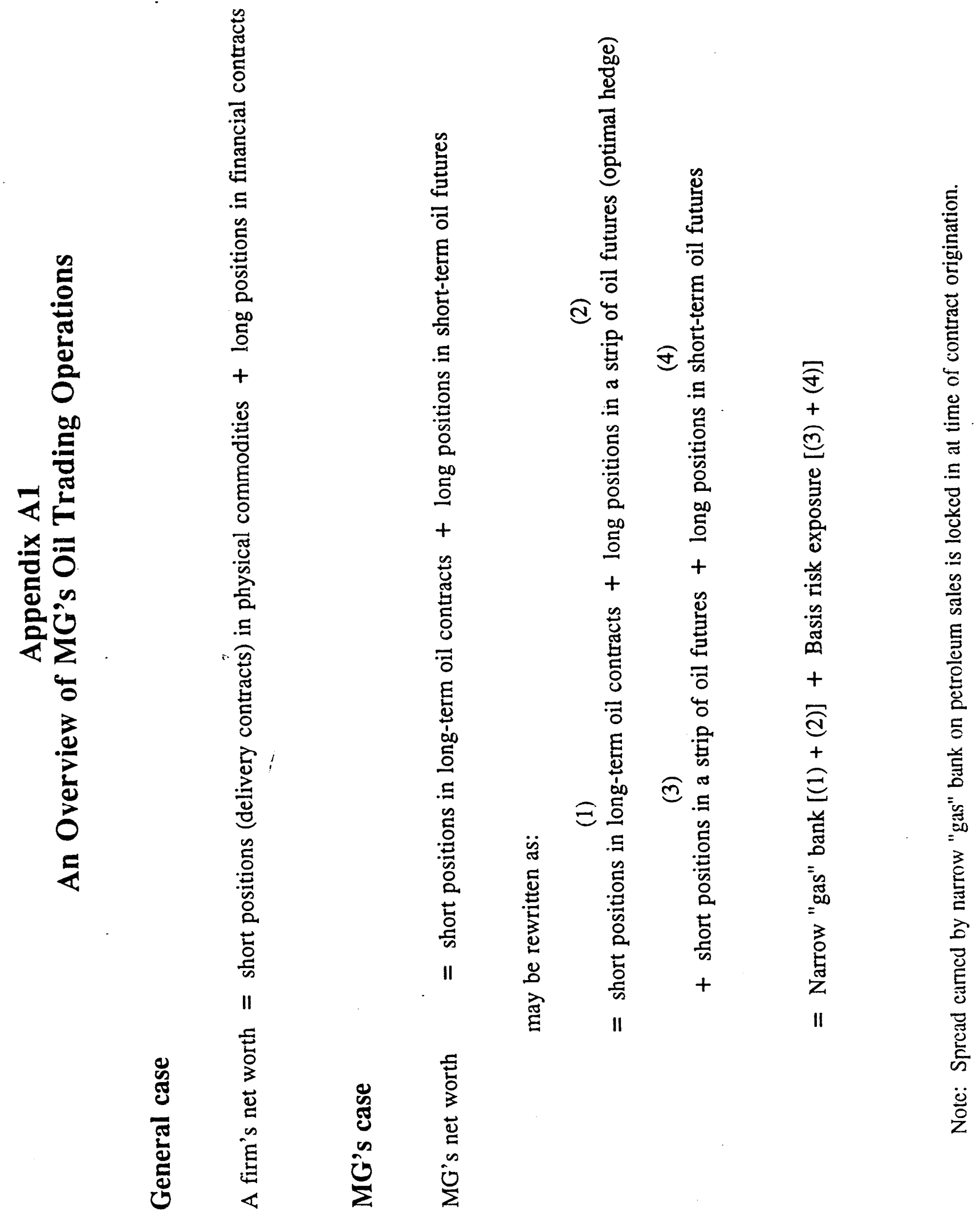




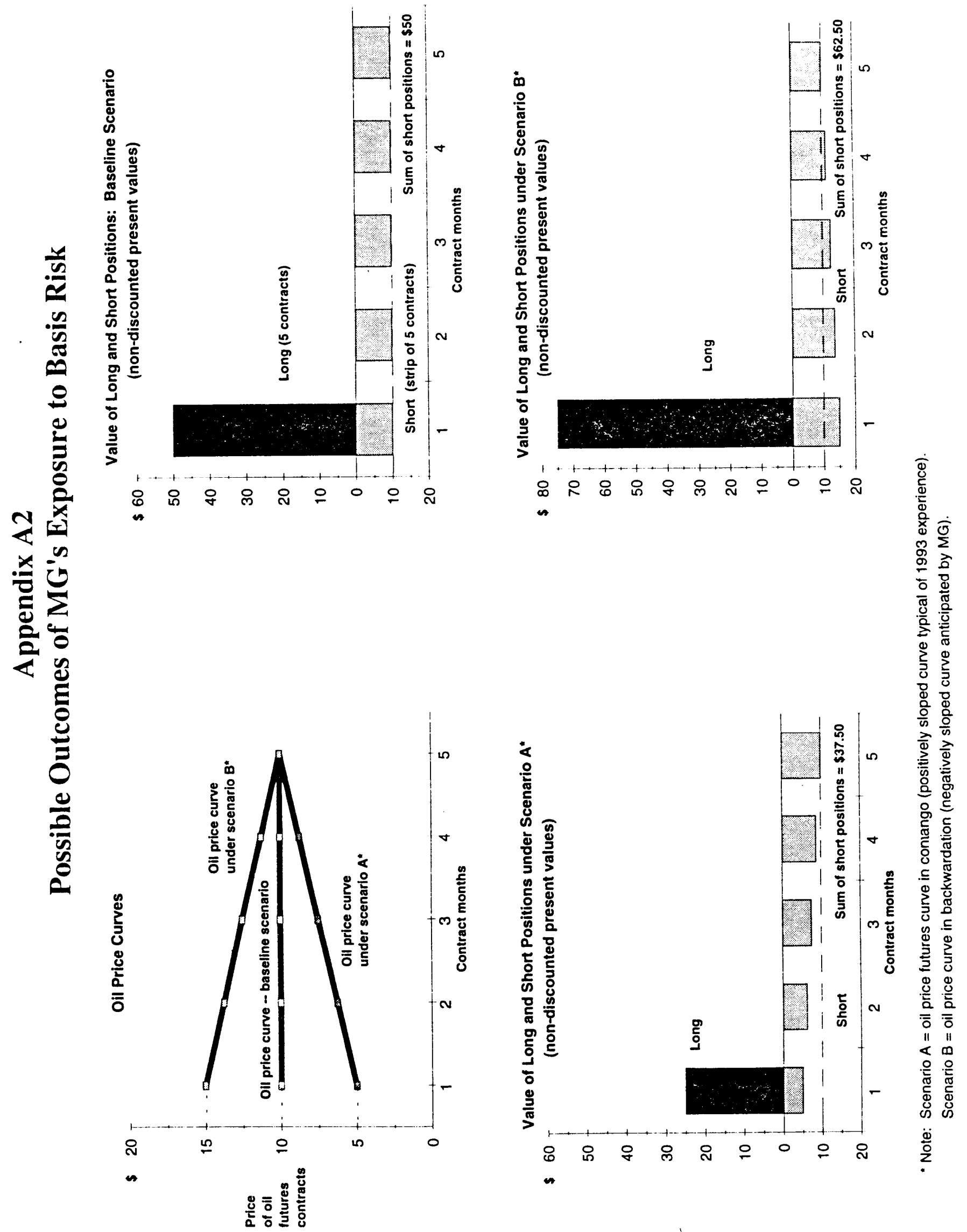




\section{Appendix B \\ Outcomes}

December 1993 - early January 1994

- Beginning of December 1993: N:G started having extreme difficulty meeting margin calls on NYMEX. MG required liquidity support of $\$ 1$ billion to finance futures and swaps positions.

- December 6: Revelations of losses appeared in the German press. MG share price fell 13 percent.

- December 10: Deutsche Bank and Dresdner Bank agreed to provide a DM1.5 billion collateralized bridge loan.

- December 10: NYMEX notified MGR\&M that it could not expand its futures positions and that higher margin calls would be assessed.

- December 17: MG's supervisory board fired four members of MG's management board, including CEO Schimmelbusch and CFO Forster. The day before, Siegfried Hodapp, CEO at MG Corp, had resigned.

- Mid to late December: Some counterparties in OTC swap transactions refused to roll over positions with MG Corp without significant collateral; some banks showed hesitance to lend money for financing MG's position, others cancelled credit lines.

- December 28: NYMEX notified MGR\&M that it had to reduce positions on the exchange, and that in the future, positions could not exceed limits imposed by NYMEX.

- December 30: By this date, approximately 80 percent of the firm-flexible supply contracts had been terminated.

- End December: Share price had fallen an additional 20 percent since December 6.

- January 5, 1994: MG's new management announced revised losses of DM1.8 billion, stating that the concern would require a sizable capital injection to avoid bankruptcy. 


\section{International Finance Discussion Papers}

IFDP

Number

560

559
Titles

Author(s)

$\underline{1996}$

The Management of Financial Risks at German Nonfinancial Firms: The Case of Metallgesellschaft

Broad Money Demand and Financial Liberalization in Greece

Stockholding Behavior of U.S. Households: Evidence from the 1983-89 Survey of Consumer Finances

Firm Size and the Impact of Profit-Margin Uncertainty on Investment: Do Financing Constraints Play a Role?

Regulation and the Cost of Capital in Japan: A Case Study

The Sovereignty Option: The Quebec Referendum and Market Views on the Canadian Dollar

Real Exchange Rates and Inflation in Exchange-Rate Based Stabilizations: An Empirical Examination

Macroeconomic State Variables as Determinants of Asset Price Covariances

The Tequila Effect: Theory and Evidence from Argentina

The Accumulation of Human Capital: Alternative Methods and Why They Matter

Alternatives in Human Capital Accumulation: Implications for Economic Growth

More Evidence on the Link between Bank Health and Investment in Japan

The Syndrome of Exchange-Rate-Based Stabilization and the Uncertain Duration of Currency Pegs
Allen B. Frankel David E. Palmer

Neil R. Ericsson

Sunil Sharma

Carol C. Bertaut

Vivek Ghosal Prakash Loungani

John Ammer Michael S. Gibson

Michael P. Leahy Charles P. Thomas

Steven B. Kamin

John Ammer

Martín Uribe

Murat F. Iyigun Ann L. Owen

Murat F. Iyigun Ann L. Owen

Michael S. Gibson

Enrique G. Mendoza Martín Uribe

Please address requests for copies to International Finance Discussion Papers, Division of International Finance, Stop 24, Board of Governors of the Federal Reserve System, Washington, D.C. 20551. 


\section{International Finance Discussion Papers}

IFDP

Number $\underline{\text { Titles }}$

$\underline{1996}$

547 from Multi-Country Models? and Implications of Death Foretold Perspective Nonborrowed Reserves
German Unification: What Have We Learned

Returns to Scale in U.S. Production: Estimates

Mexico's Balance-of-Payments Crisis: A Chronicle

The Twin Crises: The Causes of Banking and Balance-of-Payments Problems

High Real Interest Rates in the Aftermath of Disinflation: Is it a Lack of Credibility?

Precautionary Portfolio Behavior from a Life-Cycle

Using Options Prices to Infer PDF's for Asset Prices: An Application to Oil Prices During the Gulf Crisis

Monetary Policy in the End-Game to Exchange-Rate Based Stabilizations: The Case of Mexico

Comparing the Welfare Costs and the Initial Dynamics of Alternative Temporary Stabilization Policies

Long Memory in Inflation Expectations: Evidence from International Financial Markets

Using Measures of Expectations to Identify the Effects of a Monetary Policy Shock

Regime Switching in the Dynamic Relationship between the Federal Funds Rate and Innovations in

The Risks and Implications of External Financial Shocks: Lessons from Mexico

Currency Crashes in Emerging Markets: An Empirical Treatment
Joseph E. Gagnon

Paul R. Masson

Warwick J. McKibbin

Susanto Basu

John G. Fernald

Guillermo A. Calvo

Graciela L. Kaminsky

Carmen M. Reinhart

Graciela L. Kaminsky

Leonardo Leiderman

Carol C. Bertaut

Michael Haliassos

William R. Melick

Charles P. Thomas

Steven B. Kamin

John H. Rogers

Martin Uribe

Joseph E. Gagnon

Allan D. Brunner

Chan Huh

Edwin M. Truman

Jeffrey A. Frankel Andrew K. Rose 